\title{
Water balance of selected floodplain lake basins in the Middle Bug River valley
}

\author{
J. Dawidek ${ }^{1}$ and B. Ferencz ${ }^{2}$ \\ ${ }^{1}$ Department of Hydrology, Maria Curie-Skłodowska University, Aleja Kraśnicka 2 cd, Lublin, Poland \\ ${ }^{2}$ Department of Landscape Ecology and Nature Conservation, University of Life Sciences, Akademicka 13, \\ 22-950 Lublin, Poland
}

Correspondence to: J. Dawidek (jaroslaw.dawidek@poczta.umcs.lublin.pl) and B. Ferencz (beata.ferencz@up.lublin.pl)

Received: 10 July 2013 - Published in Hydrol. Earth Syst. Sci. Discuss.: 6 August 2013

Revised: 26 February 2014 - Accepted: 2 March 2014 - Published: 11 April 2014

\begin{abstract}
This study is the first attempt in the literature on the subject of comparing water balance components for floodplain lake basins, depending on the type of a lake connection to the parent river. Research was carried out in the Bug River valley in 2007-2011 water years. Four types of connections were distinguished in the area under study. Simple water balance equation could only be used with regard to the lakes connected to the main river via the upstream crevasses. Detailed and individual water balance equations were developed with reference to the other types of lakes. Water gains and losses varied significantly in the lakes under study. Values of horizontal water balance components (inflow and outflow) of the floodplain lake in Wola Uhruska considerably prevailed over the vertical ones (precipitation and evaporation). Inflow of the Bug River waters was diverse during the time period under study and amounted from 600000 to $2200000 \mathrm{~m}^{3} \mathrm{yr}^{-1}$. Volumes of precipitation and evaporation were rather stable and amounted to approx. $30000 \mathrm{~m}^{3} \mathrm{yr}^{-1}$. The lowest disparity between horizontal and vertical water balance components was observed in the interlevee lake. Both upstream inflow of rivers water and outflow from the lake (ranged from 0 in 2008 to $35000 \mathrm{~m}^{3} \mathrm{yr}^{-1}$ in 2009) were usually an order of magnitude higher than precipitation and evaporation from the lake surface (700$800 \mathrm{~m}^{3} \mathrm{yr}^{-1}$ ). Study showed that the values and the proportion between aforementioned vertical and horizontal water balance elements were determined by the type of a lake connection to the Bug River. Storage volume showed no relationship to the type of connection, but resulted from individual features of the lakes (location within the valley, precipitation and evaporation volume, difference between water inflow and outflow).
\end{abstract}

\section{Introduction}

Floodplain lakes (FPLs) constitute a very large group of global water bodies. The existing classifications of floodplain lakes are mostly based on their origins (Hutchinson, 1957; Drago, 1976; Chmiel et al., 2003). Drago (1989) listed the following among the most common types of FPLs: obstruction ponds, levee ponds, lateral expansion ponds, interbar ponds, overflow ponds, annexation ponds and swamps. Dawidek and Ferencz (2012) (after Chmiel et al., 2003) distinguished the following genetic types of lakes for temperate zones (based on the example of Poland): oxbow, inter-levee, anastomotic and avulsion lakes. The hydrological (the degree of filling of the basin) and ecological state mostly depends on the type of connections that the lake has to the parent river, as well as on the frequency of flooding (Tockner et al., 2000; Amoros and Bornette, 2002; Henry and Costa, 2003).

Hamilton and Lewis (1987) and Garcia de Emiliani (1997) distinguished four functional phases on the basis of the seasonal fluctuations of the hydrochemical parameters of a basin: filling, flow-through, drainage and isolation. Their approach is directly related to the flood pulse concept (Junk et al., 1989; Junk, 1997). Tockner et al. (1999) identified three types of hydrological connectivity of floodplain lakes with the river Danube: (a) disconnection, (b) seepage inflow and downstream surface connections; and (c) upstream and downstream surface connections. As for Polish floodplain lakes, four types have been recognised based on their connections to the main river: (a) confluent - which are supplied from the direction of the headwater and whose outflow is in the opposite direction (Fig. 1a); (b) contrafluent - which are both supplied and drained via the same downstream channel 
A

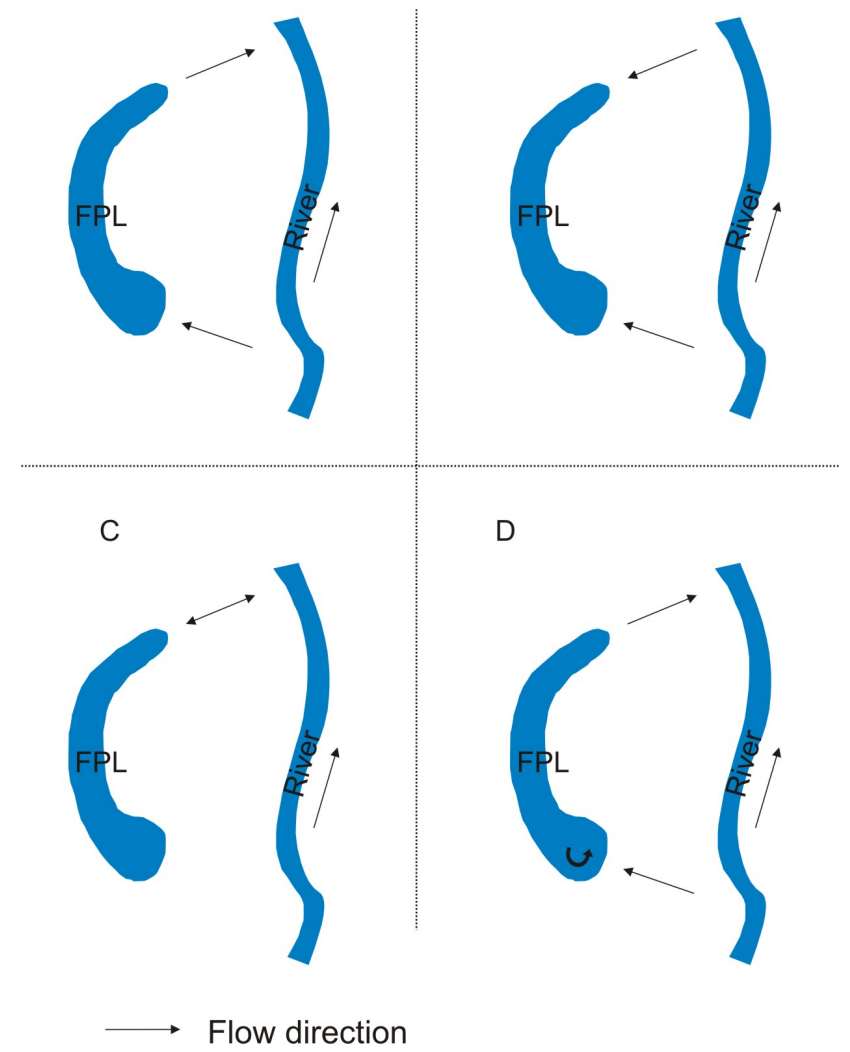

Fig. 1. Types of possible connections of the floodplain lakes to the Bug River in the present study: (A) confluent inflow, (B) contrafluent inflow, (C) contrafluent-confluent inflow, and (D) confluentprofundal inflow.

(Fig. 1b); (c) contrafluent-confluent - which are supplied downstream during periods of lower water levels; the connection between the upstream limb of the lake and the river is activated only during higher water stages (Fig. 1c), and (d) profundal ones - this type encompasses deep lakes which are intensely supplied by groundwater (Fig. 1d) (Dawidek and Turczyński, 2006).

The study of floodplain lakes is complicated by their high seasonal hydrological dynamic in terms of water level fluctuations. These changes are very difficult to predict and do not occur in such extent in other kinds of lakes. This is the reason why the calculation and the comparison of water balance elements of floodplain lake basins rarely appears in the literature. The two functional phases are most important when assessing water balance for lake basins: potamophase, which refers to the connection of a lake with a river, and limnophase, which refers to a period in which the lake is isolated. The diversity of FPLs, which is a consequence of the type of lake's connection to the parent river, necessitates adopting a standard approach to calculating water balance for lake basins. A water balance equation for floodplain lakes and river valleys which appears in the literature
(Lesack, 1993; Bonnet et al., 2008; Sriwongsitanon et al., 2009; Alsdorf et al., 2010) can be presented as follows:

$(P-E)+(I-O) \pm \mathrm{d} S / \mathrm{d} t=0$,

where $P$ denotes precipitation on the water surface, $E$ evaporation from lake's surface, $I$ inflow to the lake basin, $O$ outflow, and $\mathrm{d} S / \mathrm{d} t$ changes in lake storage

Profundal recharge is a constant and periodically high input of groundwater. This also significantly hinders the assessment of the hydrological balance for FPL basins. This form of lake basin supply clearly becomes more prevalent in the narrow sections of a floodplain which is located at the foot of an older terrace. Even a slight increase in groundwater hydraulic gradients in such areas facilitates inflow to floodplain lake basins which, due to their depth, act as a local drainage base for the water-bearing zone. The role of profundal inflow rises in the period of limnophase, as it is the only form of basin supply during without rainfall periods. The possibility of the occurrence of both potamophase and limnophase in the same month is an important event when one assesses lake water balance while maintaining the structure of monthly equations. Higher values of horizontal components of water balance are observed during potamophase period, while vertical components prevail during limnophase period.

Due to the natural character of the valley of the Bug River, the modifications of water flow result from the change of cross-sectional geometry, which is a consequence of erosion or the deposition of mineral and organic sediments in crevasses both supplying and draining the lake. The damming up of water due to the overgrowing of crevasses in summer and the formation of ice cover in winter may also hinder hydrometric measurements. The height and location of beaver dams also has a significant impact on the character of lake water runoff (in terms of quantity and time), which influences the water exchange rate and changes the water storage of a lake.

This paper aims to calculate and analyse the water balance elements of floodplain lake basins, depending on the type of the connection between the lake and the parent river (confluent, contrafluent, contrafluent-confluent or profundal). The small capacity of the lake basins referenced in this study, originating from fluvial activity of the river whose average flow rate amounts to circa $50 \mathrm{~m}^{3} \mathrm{~s}^{-1}$, allows for the hypothesis that horizontal (fluvial inflow and outflow) water balance elements dominate in the water balance of the lakes. We hypothesised that the type of connection between a floodplain lake and its parent river determines the relationship between the vertical (precipitation, evaporation) and the horizontal water balance elements. We also assumed that the difference between fluvial inflow and drainage, not the precipitation volume, determines the quantity of water stored in the lake basins. In the case of confluent lakes, we assumed highest stability of the volume of storage, whereas the lowest in contrafluent lakes. 


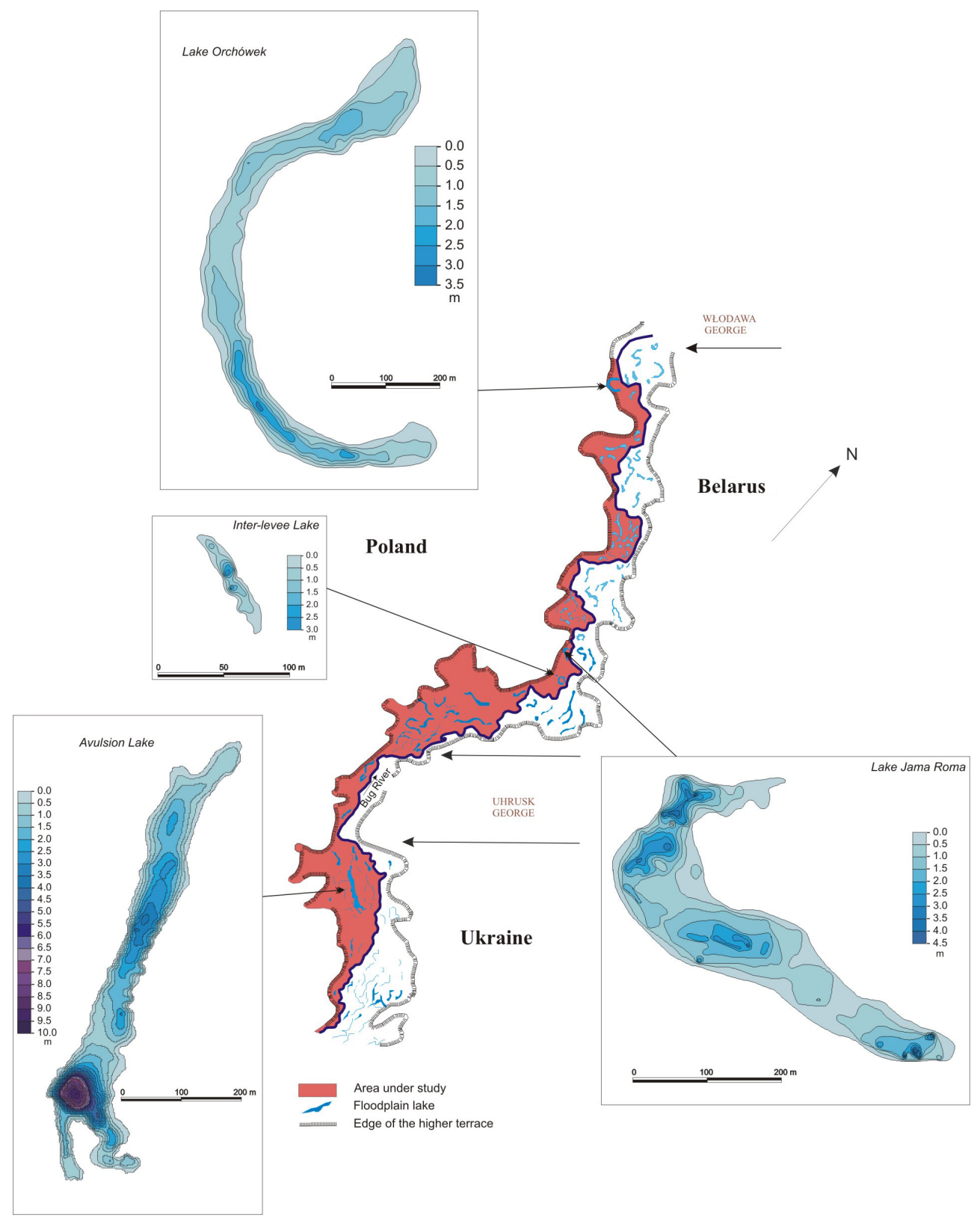

Fig. 2. Location and morphometry of the lakes under study.

\section{Study area}

Field observations were conducted in four floodplain lakes located in the valley of the Bug River between Wola Uhruska (to the south) and Włodawa (to the north). The functioning of all types of lakes, both genetic and hydrological ones, was studied in this area. The measurements of water balance components were carried out in typologically different lakes (Table 1). The climatic conditions of the Bug River basin are influenced by two substantial air masses: the polar maritime and the polar continental. Precipitation occurred most frequently in summer in the study period. Annual sums of precipitation varied from $612 \mathrm{~mm} \mathrm{yr}^{-1}$ in 2008 to $711 \mathrm{~mm} \mathrm{yr}^{-1}$ in 2011. Annual mean temperature of the study period amounted to $8.8^{\circ} \mathrm{C}$. The coldest month was February (mean temperature $-1.6^{\circ} \mathrm{C}$ ), whereas the higher temperature occurred in July (monthly mean temperature amounted to $19.4{ }^{\circ} \mathrm{C}$ ).

The studied section of the Bug River is at the Polish border (at the same time the European Union's eastern border), which is why it has maintained its almost natural character. The section of the left (Polish) fraction of the Bug River has an area of $30 \mathrm{~km}^{2}$ and is situated between noticeable narrowings of the valley, which have a gorge-like character. The 
Table 1. Selected characteristics of the lakes under study.

\begin{tabular}{lrrrll}
\hline & Area (ha) & Volume $\left(\mathrm{m}^{3}\right)$ & Depth $(\mathrm{m})$ & Hydrological type & Origin of the lake \\
\hline Lake Orchówek & 8.3 & 62200 & 2.6 & Contrafluent & Oxbow \\
Lake Jama Roma & 5.0 & 47100 & 4.9 & Contrafluent-confluent & Oxbow \\
Inter-levee lake & 0.1 & 700 & 2.5 & Confluent & Inter-levee \\
Avulsion lake & 5.5 & 89000 & 10.3 & Confluent-profundal & Avulsion \\
\hline
\end{tabular}
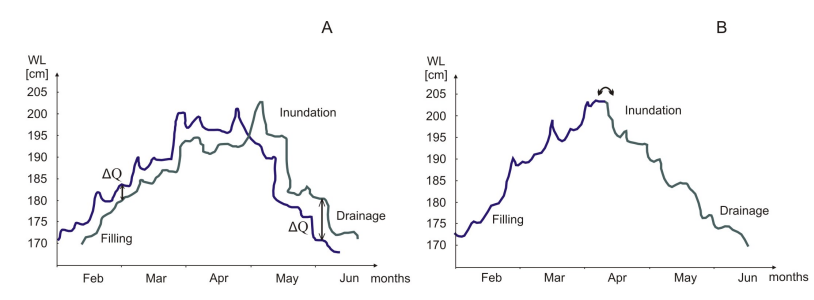

C
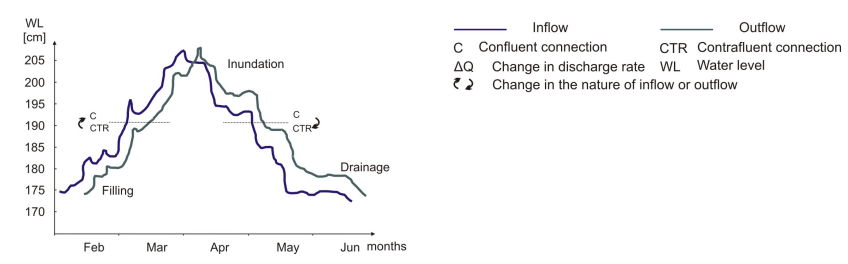

Fig. 3. Hydrographs of floodplain lakes under study depending on the connection to the Bug River: (A) - confluent lakes, (B) - contrafluent lakes, and (C) - contrafluent-confluent lakes.

western border of the study area was marked by the morphological edge of an older terrace, which was a noticeable terrain feature (Fig. 2).

\section{Methods}

\subsection{The water balance for floodplain lake basins}

There is a significant limitation to the practical applicability of the commonly used water balance equations. Namely, just as for floodplain lakes, they can only be used with regard to the cases and periods in which there is confluent inflow to lake basins (Fig. 3a).

A wide disparity between the volume of water feeding the floodplain lake basins (in a short time period) and the volume of the basins themselves makes balancing of water resources difficult. Generally, it can be said that the small storage capacity of lake basins is used up very quickly and that the lake supply dynamic necessitates intensive horizontal water exchange. The period of potamophase culmination is particularly important. At the time of the maximum rate of fluvial supply to the lakes, the values of lake water inflow and outflow are even (or very similar). A small storage capacity does not modify the transit of water through a basin in the slightest.
In case of contrafluent lakes, two equations should be solved separately: one for filling (Eq. 2), $\mathrm{PF}(+)$, and the other for draining (Eq. 3), $\mathrm{PF}(-)$, parts of potamophase.

$(P-E)+I_{\mathrm{CTR}} \pm \mathrm{d} S / \mathrm{d} t=0$,

and

$(P-E)-O_{\mathrm{CTR}} \pm \mathrm{d} S / \mathrm{d} t=0$,

where $P$ denotes precipitation on the lake surface $\left(\mathrm{m}^{3}\right)$, $E$ evaporation from the lake surface $\left(\mathrm{m}^{3}\right), I_{\mathrm{CTR}}$ contrafluent inflow $\left(\mathrm{m}^{3}\right), O_{\mathrm{CTR}}$ contrafluent outflow $\left(\mathrm{m}^{3}\right)$, and $\mathrm{d} S / \mathrm{d} t$ changes in storage $\left(\mathrm{m}^{3}\right)$.

This is necessary because of the difference between the components of fluvial water inflow and outflow during river supply or drainage to a basin. When, during potamophase, water stages rise, there is only water inflow to a basin and there is no active outflow (Fig. 3b). However, when water stages decrease there is only outflow and no inflow. The compatibility of the distribution of potamophase with monthly distribution occurs very rarely, which in practice makes it necessary to include both cases (often repeatedly) as part of 1 month for which the water balance is calculated.

Water balance equations for contrafluent-confluent lake basins have the most complicated form (Eqs. 4-5). This is because they combine both of the aforementioned cases to a varying extent. During the many months for which water balance is calculated, one should take into account fluvial contrafluent supply, with both the filling $(\mathrm{PF}+)$ and drainage $(\mathrm{PF}-)$ phase, and then confluent supply and drainage after the type of inflow to a basin has changed (Fig. 3c). After the threshold between contrafluent and confluent supply has been crossed, this complex cycle ends with the contrafluent drainage of a basin.

The equation for filling stage takes the following form:

$(P-E)+I_{\mathrm{CTR}}+\left(I_{\mathrm{C}}-O_{\mathrm{C}}\right) \pm \mathrm{d} S / \mathrm{d} t=0$,

and for drainage stage:

$(P-E)+\left(I_{\mathrm{C}}-O_{\mathrm{C}}\right)-O_{\mathrm{CTR}} \pm \mathrm{d} S / \mathrm{d} t=0$,

where $P$ denotes precipitation on the lake surface $\left(\mathrm{m}^{3}\right), E$ evaporation from the lake surface $\left(\mathrm{m}^{3}\right), I_{\mathrm{C}}$ confluent inflow $\left(\mathrm{m}^{3}\right), I_{\mathrm{CTR}}$ contrafluent inflow $\left(\mathrm{m}^{3}\right), O_{\mathrm{C}}$ confluent outflow $\left(\mathrm{m}^{3}\right), O_{\mathrm{CTR}}$ contrafluent outflow $\left(\mathrm{m}^{3}\right)$, and $\mathrm{d} S / \mathrm{d} t$ changes in storage $\left(\mathrm{m}^{3}\right)$. 
The duration of particular phases depends on both the rate of increase and decrease of river water stages and the altitude of the connecting crevasse. Therefore, in order to solve a water balance equation for contrafluent-confluent lakes, one must be particularly careful and consistent when making measurements of flow rates and maintain a necessary methodical coherence (the same measurement equipment) based on modern (precise) flow sensors.

\subsection{Field measurements}

The field measurements were carried out during water years 2007-2011. The amount of atmospheric deposition to the studied lakes was calculated based on daily measurement data obtained from the meteorological stations of the Institute of Meteorology and Water Management in Włodawa, Hańsk and Dorohusk. The atmospheric precipitation to particular floodplain lakes was calculated using Thiessen polygon method (Faisal and Gaffar, 2012). The amount of precipitation registered at the Włodawa station was adopted for Lake Orchówek; the amount recorded at the Hańsk station was applied to lakes located at the Zbereże section of the valley - Jama Roma and inter-levee lake - and the amount recorded at the Dorohusk station was adopted for the avulsion lake, which is located near the village of Wola Uhruska. Evaporation from the surface of the lake was calculated using Ivanov's formula, which was acceptable in similar studies (Leśny and Juszczak, 2005; Marciniak and Szczucińska, 2007; Ahmadi, 2012). An algorithm, which was based on the close relationship between the amount of evaporation from the surface of the lake and meteorological conditions, took into account the average monthly values of the air temperature and relative humidity. These parameters were measured at the Włodawa gauging station. The volume of the water storage was obtained by calculating the difference between the degree of lake basin repletion, which corresponded to the beginning and end of each month for which water balance was assessed (Eq. 6).

$\mathrm{d} S / \mathrm{d} t=\mathrm{Ve}-\mathrm{Vb}$,

where $\mathrm{d} S / \mathrm{d} t$ denotes changes in storage $\left(\mathrm{m}^{3}\right)$, Ve lake volume on the last day of a month $\left(\mathrm{m}^{3}\right)$, and $\mathrm{Vb}$ lake volume on the first day of a month $\left(\mathrm{m}^{3}\right)$.

A Nautilus 2000 flowmeter was used to establish the direction of water flow. Moreover, regular readings of lake water stages from staff gauges were made every day at 7:00 a.m. Discharge calculation using rating curve method brings about uncertainties resulting from for example unsteady flow conditions or seasonal variations of the state of vegetation (Di Baldassare and Montanari, 2009). Staff gauges with $1 \mathrm{~cm}$ scale were used in order to observe water levels. According to Smidth (2002) and Pappenberger et al. (2006), the errors of water level measurements are very small $(1-2 \mathrm{~cm})$. Flow rate measurements were taken once a week using Valeport 801 and Nautilus 2000 electromagnetic flowmeters. The current flowmeters have a measuring range of $2.5 \mathrm{~m} \mathrm{~s}^{-1}$ and zero with an error of $\pm 2 \mathrm{~mm} \mathrm{~s}^{-1}$. The degree of error amounts to $1 \%$ of the range. Flow sensors were calibrated according to the recommended specifications of the manufacturers. Daily discharges of lake inflows and outflows were determined from a rating curve. A velocity-area method was used to calculate streams discharge, which was based on Eq. (7):

$Q=A v$,

where $Q$ denotes stream discharge $\left(\mathrm{L} \mathrm{s}^{-1}\right), A$ area of the cross section $\left(\mathrm{dm}^{2}\right)$, and $v$ flow velocity $\left(\mathrm{dm} \mathrm{s}^{-1}\right)$.

In order to reduce discharge calculation errors, we increased numbers of vertical segments of measurement along the cross section, according to the European ISO EN Rule 748 (1997). If the cross-section width ranged from 1 to $3 \mathrm{~m}$, we took measurements every $1 \mathrm{dm}$; if the width ranged from 3 to $5 \mathrm{~m}$, subsections were placed every $2 \mathrm{dm}$; and if cross section width exceeded $5 \mathrm{~m}$, every $2.5 \mathrm{dm}$. Separate inflow and outflow rating curves were prepared for each stream from measurements of flow rate and channel cross section at the staff gauge locations. The volume of surface water that flowed into or out of the reservoir each day was calculated using the appropriate rating curves and level observations. $R^{2}$ exceeded 0.8 in case of every curve, $p<0.05$. The curves lay within the range of water level values at which discharge was measured. Occasionally, weir measurement methods were used in inundated places (e.g. above a beaver dam). The cross-section area of overflow $(A)$ and the flow velocity $(v)$ were assessed using the aforementioned devices. Under the conditions of different discharge, approximately 50 to 80 measurements of water flow were made annually in cross sections (of both inlet and outlet) of each floodplain lake under study. This amounted to over 2500 measurements of flow rates taken during the study period. FRIEND procedure (Flow Regimes from International Experimental and Network Data) was used for a hydrograph division (to surface and groundwater inflow and outflow). The algorithm was prepared by the Institute of Hydrology in Wallingford (United Kingdom) as part of international cooperation IHP UNESCO. The calculating procedure was based on the construction of pentads periods, in which the minimum values of flow had to fulfil the $\mathrm{Qmin}_{i-1}>0.9 \mathrm{Qmin}_{i}>\mathrm{Qmin}_{i+1}$ condition. The points selected this way created a line which reflected the underground flow (base flow).

\section{Results}

\subsection{Precipitation and evaporation}

The highest (among the lakes under study) volumes of vertical water balance components occurred in Lake Orchówek. The volume of precipitation fluctuated between 50788 and $58988 \mathrm{~m}^{3} \mathrm{yr}^{-1}$, with an average value of $54310 \mathrm{~m}^{3} \mathrm{yr}^{-1}$ during the 5-year study period (Table 2). The amount of 
Table 2. Water balance elements of the lakes under study $\left(\mathrm{m}^{3} \mathrm{yr}^{-1}\right)$.

\begin{tabular}{|c|c|c|c|c|c|c|c|c|}
\hline & $P$ & $E$ & $I_{\mathrm{CTR}}$ & $I_{\mathrm{C}}$ & Ig & $\mathrm{O}$ & $\mathrm{Og}$ & $\Delta S$ \\
\hline \multicolumn{9}{|c|}{ Lake Orchówek } \\
\hline 2007 & 52473 & 49375 & 614881 & n.o. & 92232 & 614071 & 85970 & 3908 \\
\hline 2008 & 50788 & 56930 & 101297 & n.o. & 11143 & 101050 & 10003 & -5896 \\
\hline 2009 & 58083 & 45758 & 201824 & n.o. & 18164 & 192876 & 36646 & 21273 \\
\hline 2010 & 51219 & 43623 & 575022 & n.o. & 155256 & 563683 & 62005 & 18935 \\
\hline 2011 & 58988 & 46624 & 179101 & n.o. & 25074 & 169096 & 42274 & 22369 \\
\hline \multicolumn{9}{|c|}{ Lake Jama Roma } \\
\hline 2007 & 30457 & 29982 & 173887 & 97393 & 85910 & 253236 & 63309 & 18519 \\
\hline 2008 & 30270 & 34570 & 9352 & 0 & 2712 & 4928 & 986 & 125 \\
\hline 2009 & 38032 & 27786 & 50020 & 54277 & 11355 & 103589 & 2072 & 10953 \\
\hline 2010 & 33496 & 26489 & 132381 & 38153 & 28453 & 167362 & 15063 & 10179 \\
\hline 2011 & 36333 & 28311 & 88310 & 31811 & 39602 & 116235 & 30221 & 11908 \\
\hline \multicolumn{9}{|c|}{ Inter-levee Lake } \\
\hline 2007 & 695 & 684 & n.o. & 11058 & 100 & 10581 & 973 & 487 \\
\hline 2008 & 691 & 789 & n.o. & 0 & 0 & 0 & 0 & -98 \\
\hline 2009 & 868 & 634 & n.o. & 34915 & 300 & 34655 & 693 & 494 \\
\hline 2010 & 764 & 604 & n.o. & 26237 & 1810 & 26897 & 215 & -500 \\
\hline 2011 & 829 & 646 & n.o. & 10638 & 3936 & 10476 & 733 & 345 \\
\hline \multicolumn{9}{|c|}{ Avulsion Lake } \\
\hline 2007 & 36370 & 32540 & n.o. & 2217410 & 1444912 & 2640984 & 1822279 & 5160 \\
\hline 2008 & 37732 & 37519 & n.o. & 1896893 & 941865 & 2412691 & 627300 & 8964 \\
\hline 2009 & 42420 & 30156 & n.o. & 606134 & 402984 & 846004 & 363782 & -6463 \\
\hline 2010 & 39422 & 28749 & n.o. & 4407331 & 3547039 & 4810480 & 2645764 & 25358 \\
\hline 2011 & 34609 & 30727 & n.o. & 3571940 & 3104085 & 3968647 & 3214604 & -3414 \\
\hline
\end{tabular}

$P$ - precipitation on the lake surface, $E$ - evaporation from the lake surface, $I_{\mathrm{CTR}}-$ contrafluent inflow, $I_{\mathrm{C}}-$ confluent inflow, $O-$ outflow, Ig - groundwater inflow, $\mathrm{Og}$ - groundwater outflow, $\Delta S$ - changes in storage, n.o. - not occurred.

evaporation fluctuated slightly more, that is, between 45758 and $56930 \mathrm{~m}^{3} \mathrm{yr}^{-1}$ (the average value was $48462 \mathrm{~m}^{3} \mathrm{yr}^{-1}$ ). Evaporation accounted from $79 \%$ of the amount of precipitation in 2011 to $112 \%$ in the driest year of 2008. The hydro-meteorological conditions in the first year of observations (2007) were the closest to the average conditions in the 5-year period. The amount of atmospheric precipitation to the lake Jama Roma clearly fluctuated in the period under study from 30270 to $38032 \mathrm{~m}^{3} \mathrm{yr}^{-1}$. The range of variability in the volume of water that evaporated from the surface of the lake was similar. Therefore, the meteorological conditions in the Zbereże section of the valley of the Bug River were fluctuating during the period under study, and their above-average dynamics represented a wet period. The lowest volumes of precipitation and evaporation were observed in the inter-levee lake. Precipitation in the lake surface area amounted from 691 to $868 \mathrm{~m}^{3} \mathrm{yr}^{-1}$. The range of evaporation volume was lower (Table 2). As a result, meteorological conditions of the lake might be considered as stable. The proportion of the amount of precipitation and evaporation in an avulsion lake in Wola Uhruska amounted from $71 \%$ in 2009 to $99 \%$ in 2008 . The relatively stable conditions in which the vertical components of the hydrological balance of the lake were observed emphasised the extreme variability of fluvial components and an average variability of storage values.

\subsection{Inflow and outflow}

A high amplitude of water inflow and outflow was a derivative of the unstable conditions of Lake Orchówek supply. Volumes of horizontal elements of water balance were diverse (Table 2). Fluvial inflow in 4 out of 5 water years under study was higher than outflow. The relationships between filling and drainage stages of potamophases were also characteristic in this lake. A duration of the filling phase was longer (1-3 months) than the duration of drainage phase (2-3 weeks). As compared to the amounts of precipitation and evaporation, the values of horizontal components of the water balance for the lake Jama Roma were one order of magnitude higher (Table 2). In the 4 years of the study period, the volume of water inflowing into the lake basin was higher than the outflow. In 2007 water year potamophases lasted from February to April. Relations between its positive 
(filling) and negative (drainage) parts were aligned. The relations were different during a long potamophase in the water year 2010. A filling of the lake continued, with a short interruptions, from November to March, while negative potamophase from April to July. The inflow volume was approximately three times higher than outflow during the positive potamophase $\left(116000 \mathrm{~m}^{3}\right.$ and $42000 \mathrm{~m}^{3}$, respectively). Drainage stage was shorter; however, a disparity between the outflow and inflow was lower at that time $\left(134000 \mathrm{~m}^{3}\right.$ and $97000 \mathrm{~m}^{3}$ respectively). In the inter-levee lake situated in Zbereże village, a clear similarity was observed between the volume of inflowing and outflowing water. During the water year of 2008, there was no lake connection to the Bug River. The percentage share of horizontal components in the water balance was definitely higher than the share of vertical ones (Table 2). Potamophases were transient in that lake, the longest in 2011 lasted 2 months (from December to February). A supremacy (both temporal and quantitative) of either filling or drainage was not observed during the time period under study. Different genetic forms of basin supply of avulsion lake in Wola Uhruska (fluvial and groundwater inflow) were various, whereas the dominance of the inflow from the river was constant. Underground inflow of this confluentprofundal lake varied from 0.7 to $2.7 \%$ of total inflow. Lake outflow was active for most of the year. The lake stood out against the other lakes with regards to temporal and quantitative balance between positive and negative potamophases. Short potamophases (3-14 days) generally occurred in the first 2 years of observation. The time of lake connection to the river during the remaining period ranged from 2 months in 2011 to 10 months in 2010 .

\subsection{Storage conditions}

Retention volume of Lake Orchówek ranged from -5896 to $22369 \mathrm{~m}^{3} \mathrm{yr}^{-1}$. In 2008, when the total annual atmospheric precipitation was the lowest, retention was negative and the volume of losses amounted to $-5896 \mathrm{~m}^{3} \mathrm{yr}^{-1}$ (Table 2). The storage level was relatively even in the following years, and it ranged from 18935 to $22369 \mathrm{~m}^{3} \mathrm{yr}^{-1}$. Jama Roma lake gained water throughout the study period. Changes in storage volume were pronounced and amounted from $125 \mathrm{~m}^{3} \mathrm{yr}^{-1}$ in water year 2008 to $18519 \mathrm{~m}^{3} \mathrm{yr}^{-1}$ in 2007 . High variability of retention volume was observed in the inter-levee lake (from -500 to $494 \mathrm{~m}^{3} \mathrm{yr}^{-1}$ ). A significant change in the amount of water resources in the lake basin from year to year was recorded, which rarely occurs in lakes of a different origin. The volume of storage changes in the avulsion lake varied between -3414 and $25358 \mathrm{~m}^{3} \mathrm{yr}^{-1}$. During 2 years of the observation period, a shortage of water resources of the lake basin was observed. Storage volume fluctuations usually occurred repeatedly, that is, increased in the year following a decrease in the amount of water (Table 2).

\section{Discussion and conclusions}

The issue of assessing water balance for floodplain lakes has not received recognition from many researchers in global literature. The existing publications on FPLs usually deal with natural valleys of large rivers in South America and North America (Lesack and Melack, 1995; Schemel et al., 2004; Williams et al., 2004; Acreman et al., 2007; Phlips et al., 2008; Wren et al., 2008; Alcântara et al., 2010; Affonso et al., 2011). The channels of the majority of European rivers were at some stage modified; this made floodplain lakes disappear. The relatively few remaining water bodies are usually characterised by man-controlled water flow. The difficulties in comparing the water balance values obtained for floodplain lakes in the temperate zone of Europe to those of American floodplain lakes result from the pronounced differences in the flow rates. Hamilton and Lewis (1987) calculated the volume of fluvial water for the floodplain lakes of the Orinoco Valley in the phase of filling at approx. $8 \times 10^{6} \mathrm{~m}^{3}$. The volume of the largest of the lakes under study was less than $9 \times 10^{4} \mathrm{~m}^{3}$.

The hypothesis that a dominant role among water balance elements played fluvial inflow and drainage has been confirmed in the floodplain lakes for most of the study period. The hypothesis that fluvial inflow and drainage played a dominant role among water balance elements has been confirmed in the floodplain lakes for most of the study period. Disproportions between horizontal and vertical components were various, depending on the type of lake connection to the river. The highest differences were noted in flow-through confluent lakes. The volume of horizontally exchanged water in the confluent-profundal lake in Wola Uhruska was approximately 50 times larger than the average volume of precipitation and evaporation. The disparity between the components of the water balance equation for the confluent interlevee lake in Zbereże was smaller. The horizontal water exchange rate resulting from confluent inflow was approximately 20 times higher than the vertical one in this lake. Lake Orchówek showed the smallest disparity between horizontal and vertical water balance components. This was connected with both natural factors and human pressure. The lake basin, which was supplied and drained via the same channel, was filled by the backwater of a river in a period of high water stages. A controlled (artificial) water distribution (a weir at the outflow), which was observed in the period under study, was designed to maintain water stages by decreasing outflow. The most stable relation between the elements of water balance occurred in the contrafluent-confluent lake Jama Roma. A supremacy of precipitation and evaporation volumes over river inflow and outflow was observed in 2008 water year, due to a lack of confluent inlet.

The structure of water balance equations for floodplain lakes in the area under study showed similarity. Horizontal component values considerably prevailed over vertical ones in majority of lakes. They were one order of magnitude (occasionally more) higher. Therefore, water balance 
equations exposed the most important features which had determined the hydrological condition of floodplain lakes, and in a broader sense, also their hydro-biological and ecological state. Water storage in the lake basin was determined by volumes of precipitation and evaporation during periods with lack of confluent inflow (in 2008 in Jama Roma and inter-levee lakes). The level of water storage in the floodplain lakes under study varied significantly. The lowest capacity characterised inter-levee lake, which was distant from the Bug River. The complicated distribution of water supplying that confluent lake caused, after fluvial inflow had been stopped, the lake to still drain the floodplain water resources of its direct catchment while maintaining basin volume for some time. Water storage resulted from fluvial inflow, as well as during periods lacking confluent supply from a quantity of precipitation and evaporation (2008). The usually longer duration of the phase of filling in relation to the phase of drainage caused the volumes of inflow to be higher than the volumes of outflow in each year of observation, and it also determined an increased basin capacity. Storage value in lake Orchówek resulted from both the river supply and the quantity of evaporated water. Human pressure caused higher volume of inflow than the volume of outflow. Positive retention was observed in 4 out of the 5 years under study. In 2008, despite larger fluvial supply, water shortage occurred in the lake basin. Evaporation was facilitated by the damming up of water and the shallow lake basin. A high variability of fluvial inflow and drainage occurred in the avulsion lake. Volume of water stored in the lake basin was low in comparison with the lake volume as well as every measured form of lake feeding and drainage. Groundwater inflow played an important role. The highest value of storage occurred in periods with intensive groundwater inflow, whereas the lowest storage in years in which groundwater inflow was the lowest.

The 5-year period under study showed that the highest storage level accompanied the highest dynamics of discharge in lakes with undisturbed water distribution. The volume of the retained water was mostly determined by the orographic features of direct catchment area and, to a lesser extent, by morphometric factors of the lake basin. The hypothesis that retention volume results from the difference between fluvial inflow and outflow, with minimum role of atmospheric deposition, has not been confirmed. Jama Roma was the only water body which gained water in all the years in which fluvial inflow dominated over the outflow. However, quantity of gains and losses (in 2008-2011 period) was also determined by a relationship between precipitation and evaporation. In other lakes in water year 2008 and in the avulsion lake in 2007 and 2010 also, the volume of storage was not determined strictly by the river inflow and drainage. To conclude, the fluctuations in the volume of retention was not affected by the type of hydrological connection of the floodplain lake to the Bug River.

Edited by: N. Basu

\section{References}

Acreman, M. C., Fisher, J., Stratford, C. J., Mould, D. J., and Mountford, J. O.: Hydrological science and wetland restoration: some case studies from Europe, Hydrol. Earth Syst. Sci., 11, 158-169, doi:10.5194/hess-11-158-2007, 2007.

Affonso, A. G., de Queiroz, H. L., and de Moraes Novo, E. M. L.: Limnological characterization of floodplain lakes in Mamirauá Sustainable Development Reserve, Central Amazon (Amazonas State, Brazil), Acta Limnol. Bras., 23, 95-108, doi:10.4322/actalb.2011.023, 2011.

Ahmadi, M. A.: Evaluation of tourism climate comfort in order to attract more tourists - Case study: Sanandaj city in Iran, Life Sci. J., 9, 623-629, 2012.

Alcântara, E., Novo, E., Stech, J., Lorenzzetti, J., Barbosa, C., Assireu, A., and Souza, A.: A contribution to understanding the turbidity behaviour in an Amazon floodplain, Hydrol. Earth Syst. Sci., 14, 351-364, doi:10.5194/hess-14-351-2010, 2010.

Alsdorf, D., Han, S. C., Bates, P., and Melack, J.: Seasonal water storage on the Amazon floodplain measured from satellites, Remote Sens. Environ., 111, 2448-2456, doi:10.1016/j.rse.2010.05.020, 2010.

Amoros, C. and Bornette, G.: Connectivity and biocomplexity in water bodies or riverine floodplains, Freshwater Biol., 47, 761776, 2002.

Bonnet, M. P., Barroux, G., Martinez, J. M., Seyler, F., MoreiraTurcq, P., Cochonneau, G., Melack, J. M., Boaventura, G. Maurice-Bourgoin, L., León, J. G., Roux, E., Calmant, S., Kosuth, P., Guyot, J. L., and Seyler, P.: Floodplain hydrology in an Amazon floodplain lake (Lago Grande de Curuaí), J. Hydrol., 349, 18-30, doi:10.1016/j.jhydrol.2007.10.055, 2008.

Chmiel, S., Dawidek, J., Szwajgier, W., and Turczyński M.: Genetic types and transformations of lakes in the Middle Bug valleyfloor, Limnol. Rev., 3, 31-36, 2003.

Dawidek, J. and Ferencz, B.: Hydrological processes in the riverine systems, the origin and classifications of floodplain lakes, Ecológia (Bratislava), 31, 331-340, 2012.

Dawidek, J. and Turczyński, M.: Feeding of lakes in the middle Bug River valley by river waters, Limnol. Rev., 7, 65-72, 2006.

Di Baldassarre, G. and Montanari, A.: Uncertainty in river discharge observations: a quantitative analysis, Hydrol. Earth Syst. Sci., 13, 913-921, doi:10.5194/hess-13-913-2009, 2009.

Drago, E. C.: Origen y clasificacion de ambientes leneticos en llanuras alluviales, Revista de la Asociacion de Ciencias Naturales Argentina, 7, 123-137, 1976.

Drago, E. C.: Morphological and hydrological characteristic of the floodplain ponds of the Middle Parana River (Argentina), Rev. Hydrobiol. Trop., 22, 183-190, 1989.

European ISO EN Rule 748: Measurement of liquid flow in open channels - velocity-area methosd, Reference number ISO 748: 1997 (E), International Standard, 1997.

Faisal, N. and Gaffar, A.: Development of Pakistan's new area weighted rainfall using Thiessen polygon method, Pakistan Journal of Meteorology, 9, 107-116, 2012.

García de Emiliani, M. O.: Effects of water level fluctuations on phytoplankton in a river-floodplain lake system (Paraná River, Argentina), Hydrobiologia, 357, 1-15, 1997.

Hamilton, S. K. and Lewis, W. M.: Causes of seasonality in the chemistry of a lake on the Orinoco River floodplain, Venezuela, Limnol. Oceanogr., 32, 1277-1290, 1987. 
Henry, R. and Costa, M. L. R.: As macrófitas como fator de heterogeneidade espacial: um estudo em três lagoas com diferentes conectividades com o rio Paranapanema, in: Ecologia e manejo de macrófitas aquáticas, edited by: Thomaz, S. M. and Bini, L. M., EDUEM, Maringá, 189-210, 2003.

Hutchinson, G. E.: A treatise of limnology, Wiley, New York, 1, 1015 pp., 1957.

Junk, W. J.: The Central Amazon Floodplain: Ecology of a Pulsing System, Ecological Studies 126, Springer, Berlin, 525 pp., 1997.

Junk, W. J., Bayley, P. B., and Sparks, R. E.: The flood pulse concept in river floodplain systems, Can. Spec. Publ. Fish. Aquat. Sci., 106, 110-127, 1989.

Lesack, L. F. W.: Water balance and hydrologic characteristics of a rainforest catchment in the central Amazon basin, Water Resour. Res., 29, 759-773, 1993.

Lesack, L. F. W. and Melack, J. M.: Flooding hydrology and mixture dynamics of lake water derived from multiple sources in an Amazon floodplain lake, Water Resour. Res., 31, 329-345, 1995.

Leśny, J. and Juszczak, R.: Evaluation of evapotranspiration of areas located within the zone of direct impact of small water reservoirs in agricultural landscape, Acta Agrophys., 6, 161-174, 2005.

Marciniak, M. and Szczucińska, A.: Measurements of selected water balance components in Ebbaelva catchments, Svalbard - pilot study, Landform Anal., 5, 51-54, 2007.

Pappenberger, F., Matgen P., Beven, K. J., Henry, J. B., Pfister, L., and de Fraipont, P.: Influence of uncertain boundary conditions and model structure on flood inundation predictions, Adv. Water Resour., 29, 1430-1449, 2006.
Phlips, E. J., Havens, K. E., and Marques Lopes, M. R.: Seasonal dynamics of phytoplankton in two Amazon floodplain lakes of varying hydrologic connectivity to the main river channel, Archiv für Hydrobiol., 172/2, 99-109, doi:10.1127/18639135/2008/0172-0099, 2008.

Schemel, L. E., Sommer, T. R., Müller-Solger, A. B., and Harrell, W.,C.: Hydrologic variability, water chemistry, and phytoplankton biomass in a large floodplain of the Sacramento River, CA, USA, Hydrobiologia, 513, 129-139, 2004.

Smidth, A. R.: Analysis of stage-discharge relations for openchannel flow and their associated uncertainties, 2002.

Sriwongsitanon, N., Surakit, K. and Hawkins, P.R.: A Water Balance Budget for Bung Boraphet - A Flood Plain Wetland-Reservoir Complex in Thailand, Water 1, 54-79, doi:10.3390/w1010054, 2009.

Tockner, K., Pennetzdorfer, D., Reiner, R., Schiemer, F., and Ward, J. V.: Hydrological connectivity and the exchange of organic matter and nutrients in a dynamic river-floodplain system (Danube, Austria), Freshwater Biol., 41, 521-535, 1999.

Tockner, K., Malard, F., and Ward J. V.: An extension of the flood pulse concept, Hydrol. Process., 14, 2861-2883, 2000.

Williams, M. R., Filoso, S., and Lefebvre, P.: Effects of land-use change on solute fluxes to floodplain lakes of the central Amazon, Biogeochemistry, 68, 259-275, 2004.

Wren, D. G., Davidson, G. R., Walker, W. G., and Galicki S. J.: The evolution of an oxbow lake in the Mississippi alluvial floodplain, J. Soil Water Conserv., 63, 129-135, 2008. 